J. Product. \& Dev., 20(3): 307-324(2015)

\title{
EFFECT OF FOLIAR SPRAY WITH SOME NATURAL PLANT EXTRACTS ON EARLINESS, PRODUCTIVITY AND QUALITY OF GLOBE ARTICHOKE
}

U. M. Saif Eldeen,

Hort. Research Institute, Agric. Research Center (ARC), Giza, Egypt.

\section{ABSTRACT}

This study was conducted to estimate whether foliar spray with some natural plant extracts could enhance earliness, productivity and quality of globe artichoke hence, two field experiments were carried out during two seasons of $2012 / 2013$ and 2013/2014 at the Hort. Res. Farm of El-Bramoon, Dakahlia Governorate, to investigate the effect of foliar spray with garlic extract rates $(1,2$ and $3 \mathrm{ml} / \mathrm{L})$ and moringia leaf extract rates $(1,2$ and $3 \mathrm{ml} / \mathrm{L})$ on earliness, productivity and quality as well as chemical constituents of globe artichoke(Cynara scolymus L.) plants cv. Balady.

The main results can be summarized as follows:

The results indicated that increasing moringia leaf extract and garlic extract rates up to $3 \mathrm{ml} / \mathrm{L}$ of each were accompanied with significant increases in vegetative growth characters (plant height, Leaf area of leaves, dry weight of leaves and number of shoots/plant) and yield distribution (early, middle, late yield and total yield/fed.) compared with control.

Application of moringia leaf extract and garlic extract rates improved most head quality characteristics (head weight, length, diameter, receptacle fresh and dry matter). However, there were no significant differences in terms of head TSS in the second seasons.

Dry matter, $N, P, K$, protein, total sugars and total carbohydrates contents in receptacle were positively and significantly responded to moringia leaf extract and garlic extract rates in the two seasons.

The foliar spraying with moringia leaf extract at rates of $3 \mathrm{ml} / \mathrm{L}$ seemed to be the most effective treatment, which gave a balanced vegetative growth, a higher early yield as well as a good quality.

Moreover, this particular treatment was more beneficial compared to all other treatments.

Key words: Cynara scolymus L, Garlic extract, Moringa extract 


\section{INTRODUTION}

Globe artichoke (Cynara scolymus L) is considered as one of the most important vegetable crops in Egypt, for local consumption and exportation, either fresh or processed. It gained an important nutritional value due to its high contents of crude protein, amino acids, crude fiber, reducing and total sugars and phenolic compounds, flavonoids, inulin, fibers and many minerals (Lattanzio and Sumere, 1987). In addition, leaves, stems and industry residues are used for cattle feed (Hammouda et al., 1993 and Feleafel, 2005).

Egypt is ranked the second world producer of globe artichoke with the highest productivity per unit area in the world, it was cultivated on 17895 fed. in 2012,which produced 387,672704 ton of bud yield with an average of 9.847 ton fed. (FAO, 2012),

The production areas around Behira, Alexandria, Giza Governorates and newly reclaimed land have favorable climatic conditions to grow good quality artichoke for export marketing. The major production of globe artichoke in Egypt is obtainable usually during the months of March and April, but the optimum export window to European countries is the period from November up to February (Ghoneim, 2005). The early production through this period represents a vital importance, since the demand for either export or local market is great and the prices are high which affects the net income of globe artichoke production (Okàsha et al., 1997).

Since ancient times, plant extracts were used in many ways. at the present time, public health and environmental safety concerns encouraged the use of these natural products for improving growth, production, nutritional status and against most insect pests. The higher content of plant extracts from chemical constituents and phenol seem to have synergistic effects on growth, yield and mortality of most fungus. ( Abd El-Hamied and El-Amary,2015)

Garlic (Allium sativum ) extract contains enzymes and more than 200 chemical compounds, some of its volatiles are more important i.e. Allicin that gives garlic its antibiotic properties. Its higher contents of volatile and sulphur compounds put both in the top due to their real and essential roles they play in growth process of various crops. Also, contains minerals, vitamins, flavonoids, sulphur, ascorbic acid, trace of iodine and essential oils(El-Desouky et al., 1998).

Effect of garlic extract on plant characters has been interpreted by Sayeeda and Ahmed (2005) and El-Shayeb (2009). They reported that garlic extract showed comparatively greater efficacy on promoting growth and 
nutrition status of groundnut and EL-Desouky et al. (1998) on squash plant, Husain and EL-Rekaby ( 2006) and Abbas et al. (2007) on cucumber plant, they found that the natural extract of garlic cloves improve the growth, sex expression and fruit yield and quality. Since, these extracts contain many growth materials and essential requirements at vegetative and reproductive growth.

Ramesh et al.(2014) show that spray of garlic extract 10 and $15 \mathrm{~g} / \mathrm{L}$ on lettuce plant had significant effect include increasing in rate on the lettuce characteristics such as head length, head diameter, head width, head weight, leaf number, healthy leave number and unhealthy leave number.

Moringa is an important plant of Moringaceae family, it is the most known and widely cultivated species throughout the world for impressive effect of medication, food and industrial purposes (Fuglie,1999; Khalafalla et al., 2010; Adebayo et al., 2011; Mishra et al., 2013 and Moyo et al., 2011). Also, it is one of the neutral alternatives, being studied to achieve its effect on growth and yield of crops and thus can be promoted among farmers as a possible supplement or substitute to inorganic fertilizers (Phiri, 2010).

Fresh moringa oleifera leaves have been shown to have high zeatin which plays an important role in cell elongation and cell division that led to promote the plant growth; hence, it is used as a natural plant growth enhancer also, has anti-aging potential and protective effects in plants. In addition, its content proteins, vitamins, $\beta$ carotene, amino acids, phenolic compounds, sugars, minerals and several flavonoid pigments. (Fuglie, 2000; Siddhuraju and Becker, 2003; Marcu, 2005; Nagar et al., 2006; Anwar et al., 2007 and Jacob and Shenbagaraman, 2011).

Moreover, moringia leaf extract was sprayed onto leaves of onions, bell pepper, soya beans, sorghum, chili, melon and maize and was shown to accelerated growth, increased leaf duration, increased number of roots, and generally increased yield of these crops (Fuglie, 2000).

Furthermore, Azra, (2011) and EL-Sayed et al. (2014) found that spraying wheat, peas and tomato with $M$. oleifera extract increased all growth parameters, productivity and crop characteristics.

In addition, Mona (2013) found that spraying rocket (Eruca vesicaria subsp. sativa) plants with the aqueous extracts of $M$. oleifera at rates of 1,2 and 3\% increased all measured growth criteria (plant height), the amounts of each of chlorophyll a and b, total sugars, ascorbic acid and N, P and $\mathrm{K}$.

In light of the above discussion, therefore, the object of this work was to investigate the effect of foliar spraying with garlic extract and moringia leaf extract on earliness, productivity and quality of globe artichoke. 


\section{MATRIALS AND METHODES}

Two field experiments were conducted at the Baramoon Research Station, Mansoura, Dakahlia Governorate, Egypt $\left(+7 \mathrm{~m}\right.$ altitude, $30^{\circ} 11$ latitude and $28^{\circ} 26$ - longitude), during seasons of 2012/2013 and 2013/2014, to study the effect of foliar spray with garlic extract and moringia leaf extract at different rate on earliness , productivity ,quality and chemical constituents of globe artichoke (Cynara scolymus L.).

Table 1 shows some physical and chemical properties of the experiment soil before planting, according to the methods described by Black (1982).

Table 1:Some physical and chemical properties of the experimental soil.

\begin{tabular}{|c|c|c|c|c|c|}
\hline \multirow[b]{2}{*}{$\begin{array}{l}\text { Physical } \\
\text { properties }\end{array}$} & \multicolumn{2}{|c|}{ Value } & \multirow[b]{2}{*}{$\begin{array}{l}\text { Chemical } \\
\text { Properties }\end{array}$} & \multicolumn{2}{|c|}{ Value } \\
\hline & $\begin{array}{c}1^{\text {st }} \\
\text { Season }\end{array}$ & $\begin{array}{c}2^{\text {nd }} \\
\text { Season }\end{array}$ & & $\begin{array}{c}1^{\text {st }} \\
\text { Season }\end{array}$ & $\begin{array}{c}2^{\text {nd }} \\
\text { Season }\end{array}$ \\
\hline Sand $(\%)$ & 27.2 & 27.5 & pH value & 8.1 & 7.9 \\
\hline Silt (\%) & 31.5 & 31.4 & $\mathrm{EC} \mathrm{dSm}^{-1}$ in soil & 0.9 & 0.8 \\
\hline Clay (\%) & 41.3 & 41.1 & Total N (\%) & 0.03 & 0.04 \\
\hline Texture class & Clay-loam & Clay-loam & Available P (ppm) & 11.3 & 11.5 \\
\hline $\mathrm{CaCO}_{3}(\%)$ & 3.1 & 3.2 & Available K (ppm) & 306 & 298 \\
\hline
\end{tabular}

Experimental design was randomized complete block with three replicates. The planting dates were 15 and 19 of August in the $1^{\text {st }}$ and $2^{\text {nd }}$ seasons, respectively. Pre-planting, the old grown pieces (stumps) were treated with fungicides for 30 minutes and hand planted at $1 \mathrm{~m}$ apart between each two plants on the ridge and $1 \mathrm{~m}$ between the ridges. Plot area was $24 \mathrm{~m}^{2}$ (4 lines $\times 6 \mathrm{~m}$ long $\times 1 \mathrm{~m}$ width). Other agriculture practices and pest control were applied as commonly recommended for commercial globe artichoke production by Ministry of Agriculture.

The experiment included seven treatments as follows:

1-Control (tap water)

2- Garlic extract $1 \mathrm{ml} / \mathrm{L}$

3- Garlic extract $2 \mathrm{ml} / \mathrm{L}$

4- Garlic extract $3 \mathrm{~m} / \mathrm{L}$

5- Moringia leaf extract $1 \mathrm{~m} / \mathrm{L}$

6- Moringia leaf extract $2 \mathrm{ml} / \mathrm{L}$

7- Moringia leaf extract $3 \mathrm{ml} / \mathrm{L}$ 


\section{Garlic extract:}

According to EL-Desouky et al. (1998) the garlic extract was prepared, hence, fresh mature garlic cloves were blended in distilled water $100 \mathrm{~g}$ cloves/ liter distilled water. Frozen and thawed two times then filtered. The final extracts were collected separately in other dark glass bottles then stored in a refrigerator at $5{ }^{\circ} \mathrm{C}$ until needed.

Main contents of garlic extract have been analyzed by Arid Land Agricultural Research Unit Fac. of Agric. Ain Shams Univ. in Table 2.

Table 2: Some chemical constituents of garlic cloves

\begin{tabular}{|c|c|}
\hline Components & Concentration \\
\hline $\mathrm{GA} 3$ & $1.633 \mathrm{mg} / 100 \mathrm{gm} \mathrm{F} . \mathrm{W}$ \\
\hline $\mathrm{IAA}$ & Trace amount \\
\hline $\mathrm{ABA}$ & Trace amount \\
\hline $\mathrm{Ca}$ & $1.363 \%$ \\
\hline $\mathrm{Mg}$ & $1.230 \%$ \\
\hline $\mathrm{S} 04$ & $0.181 \%$ \\
\hline $\mathrm{Zn}$ & $66.5 \mathrm{ppm}$ \\
\hline $\mathrm{Mn}$ & $94.4 \mathrm{ppm}$ \\
\hline
\end{tabular}

\section{Moringa leaf extract:-}

According to Culver et al. (2012), moringa leaf extract was prepared as follow: An amount of $20 \mathrm{~g}$ of young moringa leaves (shoots were harvested at 35 days after emergence) was mixed with $675 \mathrm{ml}$ of $80 \%$ ethanol. The suspension was stirred using a homogenizer to help maximize the amount of the extract. The solution was then filtered by wringing the solution using a mutton cloth. The solution was re-filtered using No. 2 Whatman filter paper. The extract was diluted with distilled water at a ratio 1:32 (v/v) and then sprayed directly onto plants. The extract was used within five hours from cutting and extracting (if not ready to be used, the extract or the solution prepared was stored at $0{ }^{0} \mathrm{C}$ and only taken out when needed for use).

Spraying treatments were applied four times started after 45 days from planting date and repeated every 15 days through the growth season.

\section{Studied characteristics}

Plant growth parameters:

A randomly chosen sample of five plants / plot was picked up after 120 days from planting date to determine plant height, dry weight of leaves /plant and number of shoots/plant. leaf area/ plant was determined according to Koller (1972). 


\section{Yield distribution:}

All flower heads of plants in each plot were harvested and counted to study yield distribution and to determine early yield, was calculated from the start of harvest until the end of February, middle yield, was harvested during March and late yield was harvested during April up to end of May. The total yield was calculated as ton/fed.

\section{Heads quality characteristics:}

At the peak of harvesting period (March), head quality characters were considered and the following measurements and determinations were achieved; average head weight, length and diameter, receptacle fresh weight and dry weight of receptacle as well as total soluble solids (TSS) in the edible portions, using a hand refract meter.

\section{Chemical constituents:}

At 120 days after planting, dry matter of receptacle, were finely ground and wet digested for $\mathrm{N}, \mathrm{P}$ and $\mathrm{K}$ determination;

- Nitrogen concentration was determined by Nesslar method according to AOAC (1995).

- Phosphorus was estimated calorimetrically using the reduced molybdophosphoric blue color method according to Jackson (1970).

- Potassium was determined using the flame photometer (CORNING, M 410).

-Total sugars and total carbohydrate in head receptacles were determined according to the methods described by Forsee (1938) and Michel et al. (1956), respectively.

-Total protein was determined by multiplying nitrogen content by 6.25 according to AOAC (1995).

\section{Statistical analysis:}

All recorded data were subjected to statistical Analysis of Variance and least significance differences (Duncan's, 1955) at 0.05 level of probability to separate means, as mentioned by Sndecor and Cochran (1980).

\section{RESULTS AND DISCUSSION}

\section{1-Vegetative growth characteristics:}

The results presented in the Table (3) clearly revealed that, foliar spraying of natural plant extracts "garlic and moringa" significantly had influence on all growth characters (plant height, leaf area of leaves, dry weight of leaves and number of shoots/plant) in the two seasons. The highest values of growth characters included (plant height, leaf area of 
leaves, dry weight of leaves and number of shoots/plant) were recorded by foliar spray with moringa leaf extract at $3 \mathrm{ml} / \mathrm{L}$. Meanwhile, the lowest values were found by control treatment (foliar spray with tap water). These similar results were obtained in both seasons of study. There were no significant differences were found between foliar spray with moringa at 2 or $3 \mathrm{ml} / \mathrm{L}$ on all growth characters in the two seasons. Also, between foliar spray with garlic extract at $1 \mathrm{ml} / \mathrm{L}$ and control (tap water) in the two seasons of study.

The stimulative effect of garlic extract on vegetative growth might be attributed to being contain natural sources of many growth promoting substances (macro and micronutrients, IAA,) (El-Desouky et al., 1998).

These results are in harmony with the findings of Helmy (1992) on summer squash, El-Sawy (2007) on cucumber, Shehata et al. (2012) on cucumber, Swelam (2012) on pepper and Tartoura et al. 2013) on squash plants.

Regarding the growth enhancing potential of moringa leaf extract on increment effect on vegetative growth might be due to its role as a plant growth stimulator. It being a rich source of vitamins, essential macro and micro plant minerals, , amino acids, natural antioxidants and plant growth regulators such as gibberellins and zeatin (cytokinins), it can be effectively exploited as plant growth enhancer (Makkar and Becker, 1996, Mahmood et al., 2010). These results are concerned with those of (Culver et al. 2012; Muhamman et al. 2013; Bashir et al. 2014; Yasmeen et al. 2014) on tomato, and (Ndor et al. 2012) on watermelon.

\section{Yield distribution:}

Foliar spraying of natural plant extracts garlic and moringa on early, medium, late and total yield/fed. were illustrated in Table 4. Results proved that spraying globe artichoke plants with garlic and moringa extracts at different tested rates resulted in a significant improvement in yield distribution in both seasons, compared with control. The highest rate of moringa leaf extract $(3 \mathrm{ml} / \mathrm{L})$ resulted in highest yield distribution in the first and second seasons, respectively. The moringa leaf extract at $2 \mathrm{~m} / \mathrm{L}$ had a similar effect to that of moringa leaf extract at $3 \mathrm{~m} / \mathrm{L}$ on most characters of study. The increases in early yield than control treatment were about 6.9, $38.0,75.6,61.0,80.5,86.6$ in the $1^{\text {st }}$ season and 17.1, 22.4, 56.5, 49.1, 72.4 and $80.5 \%$ as for garlic extract at 1,2 and $3 \mathrm{~m} / \mathrm{L}$ and moringa extract at 1,2 and $3 \mathrm{ml} / \mathrm{L}$ in the $2^{\text {nd }}$ season. Such foundation may be due to the role of both garlic extract and moringa leaf extract in, exhibition different regulatory and defensive roles through elicitation and signaling of different physiological and metabolically processes. 
Garlic extract is a natural product with anti-oxidative, antibiotic, anti-viralic and antifungal activities Curtis et al. (2004). It has improves the availability of soil nutrients and slows down the growth of plant antagonists Konkov and Kiram (1988). Many investigations found the favorable effect of garlic extract on plant growth and productivity on many plants (Helmy, 1992 and Shafshak et al., 2004) on squash and Bhyan et al. (2007) on okra.

The favorable effect of moringa leaf extract on yield might be connected with the role of plant growth regulators in improving crop growth and hence yield (Muhamman et al., 2013). It contains endogenous cytokinins (zeatin, dihydrozeatin and isopentyladenine) which affect on assimilate mobilization and/or distribution (Emongor, 2015). Zeatin is a plant growth hormone from the cytokinines group, it plays an important role in cell division and cell elongation (Taiz and Zeiger, 2006) and involved in carbohydrate mobilization as well as distribution to the sink where more carbohydrate are needed to cater the needs of rapidly increasing growth (Iqbal, 2014).

Moreover, Hussain et al. (2013) reported that moringa extracts accelerate the growth of plants, strengthen plants and improve resistance against pests and diseases.

\section{Heads quality characteristics:}

Data recorded in Table (5) showed that, foliar spraying with garlic and moringa extracts at different rates were responsible for significant improvements on head quality characteristics, expressed as head's weight, length, diameter, and receptacle fresh weight, dry matter and total soluble solids (TSS) compared to the control. The highest heads quality characteristics were recorded by foliar sprayed with moringa extract at $3 \mathrm{ml} / \mathrm{L}$ followed by, moringa extract at $2 \mathrm{ml} / \mathrm{L}$.

There were no significant differences between moringa extract at 3 or $2 \mathrm{~m} / \mathrm{L}$ and garlic extract at $3 \mathrm{~m} / \mathrm{L}$ on head's length and receptacle fresh weight, in the first season of study, head's diameter and receptacle dry matter in the second season of study, and TSS in the tow seasons of study. Meanwhile, the lowest values of these parameters were recorded by control treatment. These increments may be explained on the bases that all used treatments had favorable stimulatory effects on vegetative growth characters and enhanced photosynthetic apparatus, and consequently reproductive growth triggers a switch in partitioning from vegetative growth sinks to reproductive sinks. The obtained results are in a same direction with that of EL-Sayed et al. (2014) on sugar pea and Azra (2011) on wheat, peas and tomato, they found that spraying with moringa extract increased productivity and crop characteristics. 


\section{Chemical constituents:}

Data in Table (6) illustrate that receptacle contents of N,P,K, total carbohydrate $\%$, total sugars $\%$ and protein percent contents were greatly affected by all treatments compared with the control in the two seasons. moringa extract at $3 \mathrm{ml} / \mathrm{L}$ treatments were superior in their effects on all mentioned characters followed by moringa extract at $2 \mathrm{ml} / \mathrm{L}$ treatments and no significant differences between moringa extract at $2 \mathrm{ml} / \mathrm{L}$ treatments and garlic extract at $3 \mathrm{ml} / \mathrm{L}$ in all studied characters except for $\mathrm{P} \%$ in the first season only. The significant increments in the obtained characters over control may be attributed to its effects on enhancing ion uptake (Marschner, 2013). Moringa leaf extract foliar application was more effective as natural biostimulant to improve fruit quality of tomato. It increased lycopene , total soluble solids, total sugar and vitamin $\mathrm{C}$ content in fruits (Yasmeen et al., 2014). Spraying garlic extracts increased chemical constituents as( N, P, K, Fe, $\mathrm{Zn}$ and $\mathrm{Mn}$ ) compared with control on squash plants (Tartoura et al., 2013).

\section{Chemical constituents:}

Data in Table (6) illustrate that receptacle contents of N,P,K, total carbohydrate $\%$, total sugars $\%$ and total protein $(\%)$ were greatly affected by all treatments compared with the control in the two seasons. Moringa extract at $3 \mathrm{ml} / \mathrm{L}$ was superior in their effects on all mentioned characters followed by moringa extract at $2 \mathrm{ml} / \mathrm{L}$ and without significant differences between moringa extract at $2 \mathrm{ml} / \mathrm{L}$ or garlic extract at $3 \mathrm{ml} / \mathrm{L}$ except $\mathrm{P} \%$ in $1^{\text {st }}$ season only. The significant increments in the obtained characters over control may be attributed to its effects on enhancing ion uptake (Marschner, 2013). Moringa leaf extract foliar application was more effective as natural biostimulant to improve fruit quality of tomato. It increased lycopene, total soluble solids, total sugar and vitamin C content in fruits (Yasmeen et al., 2014). and Tartoura et al. (2013) found that spraying garlic extracts increased chemical constituents as ( N, P, K, Fe, Zn and Mn) compared with control on squash plants .

\section{REFERENCES}

A.O.A.C. (1995). Association Of Official Agricultural Chemists . Official Systems Of Analysis. 17 ${ }^{\text {th }}$. ed. A.O.A.C., Wash., D.C

Abbas M.J., A.N. Jerry M.H. and M.H. Fayadh (2007). Effect of plant extracts and growth regulators on endogenous hormones and carbohydrate of snak cucumber (Cucumis melovar Flexueses Naud) and cucumber (Cucumis sativus L.). J. Kerbala University Iraq, 5: 274-283. 
Abd El-Hamied, S.A. and E.I. El-Amary (2015). Improving growth and productivity of "pear" trees using some natural plants extracts under North Sinai conditions. Journal of Agriculture and Veterinary Science, 8(1): 1-9.

Adebayo A.G; H. A. Akintoye; O.O. Olufolaji; M.T. Aina; M.T. Olatunji and A. O. Shokalu (2011). Assessment of organic amendments on vegetative development and nutrient uptake of moringa oleifera $\mathrm{L}$. in the nursery. Asian J. Plant Sci., 10(1):74-79.

Anwar F., S. Latif, M. Ashraf and A. H. Gilani (2007). Moringa oleifera: A food plant with multiple medicinal uses. Phytother. Research, 21:17-25.

Azra Y. (2011). Exploring the potential of moringa (Moringa Oleifera) leaf extract as natural plant growth enhancer. Ph.D. Faculty of Agriculture, University of Agriculture, Faisalabad, Pakistan.

Bashir, K.A., J.A. Bawa, and I. Mohammed (2014). Efficacy of leaf extract of drumstick tree (Moringa oleifera Lam.) on the growth of local tomato (Lycopersicon esculentum). Journal of Pharmacy and Biological Sciences, 9(4): 74-79.

Bhyan, S.B., M.M. Alara and M.S. Ali, (2007). Effect of plant extracts on okra mosic virus incidence and yield related parameters of okra. Asian J. Agric. Res., 1(3): 112-118.

Black, C. A. (1982). Methods Of Soil Analysis. Part 2. Amer. Soci. Agron. INC. Publisher, Madison, Wisconsin, USA.

Culver, M., T.Fanuel, and A.Z. Chiteka (2012). Effect of moringa extract on growth and yield of tomato. Greener J. Agric. Sci., 2 (5): 207-211.

Curtis, H., U. Noll, J. Stomann and A.J. Slusarenko (2004). Broad spectrum activity of the volatile phytoanticipin allicin in extracts of garlic against plant pathogenic bacteria, fungi and omycetes. Phys, and Molec., Plant Path., 65: 79-89.

Duncan, D.B.(1955). Multiple rang and multiple F- test. Biometrics, 11: 1-42.

El-Desouky, S. A., A. L. A. Wanas and Z. M. A. Khedr (1998). Utilization of some natural plant extracts (of garlic and yeast) as seed-soaked materials to squash (Cucurbita pepo L.). 1- Effect on growth, sex expression and fruit yield and quality. Annals of Agric. Sci. Moshtohor, 36(2): 839-854.

El-Sawy, M.B. (2007). Effect of mulch and foliar spray with biostimulants and chemical nutrients on cucumber plants grown under plastic houses. Ph.D. Thesis, Fac. Agric., Kafrelsheikh Univ., Egypt.

El-Sayed H.A.;M.M.B. Shokr and A.A. El-Sherbini (2014). Physiological studies on sugar pea; Effect of plant density and some natural substances as foliar applications on growth, pod yield and quality. J. Plant production, Mansoura Univ., 5 (7):1259-1281. 
El-Shayeb N.S.A. (2009) Physiological studies. Oenothera biennis (Biofertilizer and plant extracts). Ph.D. Thesis, Hort. Dept., Fac. Agric, Benha Univ., Egypt.

Emongor, V.E. (2015). Effects of moringa (Moringa oleifera) leaf extract on growth, yield and yield components of snap beans (Phaseolus vulgaris). BJAST, 6(2):114-122.

FAO (2012). Food and Agricultural Orgnization of United Nations, Available at $h t t p: / / w w w$ faostat.fao.org.

Feleafel, M.N. (2005). Effects of nitrogen levels under decapitation treatments on growth, yield and quality characteristics of globe artichoke. J. Agric \& Eniv. Sci. Alex. Univ., Egypt .4 (2):25-44.

Forsee, W. T., Jr.(1938). Determination of sugar in plant materials A photometeric method. Indus. Eng. Chem. Anal. , Ed., 10:411-418.

Fuglie, L.J. (1999). The miracle tree: Moringa oleifera: Natural nutrition for the tropics.Church World Service, Dakar, 68 pp.

Fuglie, L.J. (2000). The miracle tree: Moringa oleifera: Natural nutrition for the tropics. In: The miracle tree: The multiple attributes of moringa. Wageningen, The Netherlands, 172 pp.

Ghoneim, I.M. (2005). Effect of biofertilizer types under varying nitrogen levels on vegetative growth, heads yield and quality of globe artichoke (Cynara scolymus, L.). J. Agric. and Env. Sci. Alex. Univ., Egypt , 4 (2):1-24.

Hammouda, F.M., M.M.S. El-Nasr, S.I. Ismail and A.A. Shahat (1993). Quantitative determination of the active constituents in Egyptian cultivated Cynara scolymus, L. Inter. J. Pharmacognosy, 31 (4): 299-304.

Helmy, E.M.S. (1992). Response of summer squash application method to fresh garlic extracted by different solvents. Alex. J. Agric. Res., 37: 125142.

Husain, W. A. and F.H. El-Rekaby (2006). Response of cucumber plants to foliar spray with garlic, licorice extract and urea on growth and yield. Iraqi J. Agric. Sci., 37(4): 33-38.

Hussain, M., M. Farooq, M.A. Shahzad, S.M.A. Basra, and D. Lee (2013). Application of moringa alleopathy in crops sciences. In: Cheema et al. (Eds.), Allelopathy. Springer Berlin Heidelberg, pp: 469-483.

Iqbal, M.A. (2014). Role of moringa, brassica and sorghum water extracts in increasing crops growth and yield: A Review. Am-Euras. J. Agric. and Environ. Sci., 14(11): 1150-1158.

Jackson, M. L. (1970). Soil Chemical Analysis. Prentic Hall, Englewood Ceiffs, N. J. 
Jacob S. J. P. and S. Shenbagaraman (2011). Evaluation of antioxidant and antimicrobial activities of the selected green leafy vegetables. Int. J. Pharm. Tech. Res., 3(1):148-152.

Khalafalla M.M., E. Abdellatef, H.M. Dafalla, A. A. Nassrallah, K. M. Aboul-Enein, D. A. Lightfoot, F. E. El-Deeb and H. A. El-Shemy (2010). Active principle from moringa oleifera L. leaves effective against two leukemais and a hepatocarcinoma. Afr. J. Biotech., 9(49):8467-8471.

Koller, H. R. (1972). Leaf area- leaf weight relationship in the soybean canopy. Crop Sci., 12: 180-183.

Konkov, P. F. and V. Kiram (1988). Vegetable growing in home garden of tropical and subtropical areas. MIR, Pub., Moscow, USSR.

Lattanzio, V. and C.V. Van Sumere ( 1987). Changes in phenolic compounds during the development and cold storage of artichoke (Cynara scolymus, L) heads. Food Chemistry, 24 (1): 37-50.

Mahmood, K.T, T. Mugal, and I.U. Haq (2010). Moringa oleifera : A natural gift : A review. J. Pharm. Sci. Res., 2: 775-781.

Makkar, H.P.S. and K. Becker (1996). Nutritional value and ant- nutritional compounds of whole and ethanol extracted Moringa oleifera leaves. Anim. Feed Science Technology, 63: 211-228.

Marcu M.G. (2005) Miracle Tree. KOS Health Publications, Canada, pp. 108115.

Marschner, H. (2013). Mineral Nutrition Of Higher Plants. 3 Ed., Reprinted. Academic Press, Amsterdam, The Netherlands

Michel, U., G. K. Gilles, P. Hamilton and F. Smith (1956). Colorimetric method for determination of sugar and related substances. Analytic chemistry, 28: 17-24.

Mishra, S.P.,P. Singh, S. Singh, R. Das, and R.S. Prasad (2013). Moringa oleifera leaf extract as biostimulant for increasing pea yield. Indian Forester, 139 (6): 562-563.

Mona M. A. (2013). The potential of Moringa oleifera extract as a biostimulant in enhancing the growth, biochemical and hormonal contents in rocket (Eruca vesicaria subsp. sativa) plants. International Journal of Plant Physiology and Biochemistry., Vol. 5(3), pp. 42-49.

Moyo B.,P. J. Masika, A. Hugo and V. Muchenje (2011). Nutritional characterization of Moringa (Moringa oleifera L.) leaves. Afr. J. Biotechnol., 10(60):12925-12933

Muhamman, M.A., B.M. Auwalu, A.A. Manga, and J.M. Jibrin (2013). Effects of aqueous extract of moringa (Moringa oleifera L.) and nitrogen rates on some physiological attributes and yield of tomato. Inter. $J$. Chem., Enviro. and Biolo. Sci., (1): 67-74. 
Nagar P. K. , R. I. Leyer and P. K. Sircar (2006). Cytokinins in developing fruits of Moringa pterigosperma Gaertn. Physiol. Plant, 55:45-50.

Ndor, E., S.N. Dauda, D. Anda, H.B. Chamang, and U.D. Farringoro (2012). Assessing the efficacy of aqueous leaf extract of some botanicals for control of field insects of watermelon (Citrillus lanatus) in Southern Guinea Savanna, Nigeria. Asian J. Agric. Sci., 4(5): 329-332.

Okasha, K.H.A., M.E.Ragab, H.E Wahba, A.M. Razin and M.A. Abd ElSalam( 1997). Yield, head quality and some medicinal compounds of some new imported artichoke cultivars (Cynara scolymus, L.). Zagazig J. Agric. Res., 24 (1): 101-115.

Phiri, C. (2010). Influence of Moringa oleifera leaf extracts on germination and early seedling development of major cereals. Agric. Biol. J..N. Amer., 1(5):774-777.

Ramesh F., M. R. Hassandokht and P. Moradi (2014). Effects of stinking assa and garlic extract on some traits of Lettuce and Parmacellidae (Lehmannia valentiana) Int. J. Biosci., 5 (7): 58-64.

Sayeeda F. and M.U. Ahmad (2005) Comparative efficacy of some organic amendment and a nematicide (furadN-3G) against rootknot on two local varieties of groundnut. Journal of Plant Pathol., 4: 54-57.

Shafshak, N, S., A.R.A. Aggour and S.M.M. Ali (2004). Effect of fertilization system on some squash cultivars production. The 4th Scientific Conference of Agric. Sci., Assiut, December, pp. 418-426.

Shehata, S.A., Y.M. Ahmed, E.T. Youssef and M.A. Azoz (2012). Influence of some organic and inorganic fertilizer on vegetative growth, yield and yield components of cucumber plants. Research J. of Agric. and Biological Sci., 8(2): 108-114.

Siddhuraju P. and K. Becker (2003). Antioxidant properties of various solvent extracts of total phenolic constituents from three different agro climatic origins of drumstick tree (Moringa oleifera Lam). J. Agric. Food Chem. 15:2144-2155.

Snedecor, G. W. and W. G. Cochran (1980). Statistical Methods. $7^{\text {th }}$ Ed. Iowa State Univ. Press, Iowa, USA.

Swelam, W.M.E. (2012). Effect of organic fertilizer, biofertilizer and some foliar application treatmetns on the yield and quality of sweet pepper. Ph.D. Thesis, Fac. Agric., Mansoura Univ., Egypt.

Taiz, L. and E. Zeiger (2006). Plant Physiology. $4^{\text {th }}$ Ed. Sinauer Associates, Sunderland, MA, USA, 690 pp. 
Tartoura, E A. A., E. E. El-Gamily, Y.B.A. El-Waraky and A.A.M. Fayed (2013). The impact of organic and mineral fertilizations, plant spacing and foliar application of yeast and garlic extract on seed production of squash. 1-Vegetative growth and leaf chemical constituents. J. Plant Production, Mansoura Univ., Vol. 4 (11): 1691 - 1705.

Yasmeen, A., W. Nouman, S.M.A. Basra, A. Wahid, H. Rehman, N. Hussain and I. Afzal (2014). Morphological and physiological response of tomato (Solanum lycopersicum L.) to natural and synthetic cytokinin sources: a comparative study. Acta Physiol.Plant., 36(12): 3147-3155. 


\section{تأثير الرش ببعض المستخلصات النباتية الطبيعية علي التبكير والإنتاجية

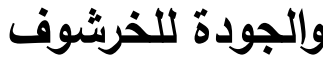

$$
\text { أسامة محمد سيف الدين معاتين - مركز البحوث الزر اعية ـ الجيزة - مصر. }
$$

أجريت هذه الدراسة لتقدير ما إذا كان الرش الورقي ببعض المض المستخلصات

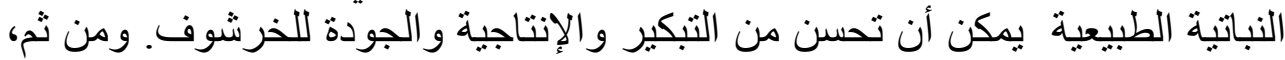

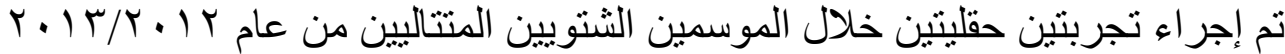

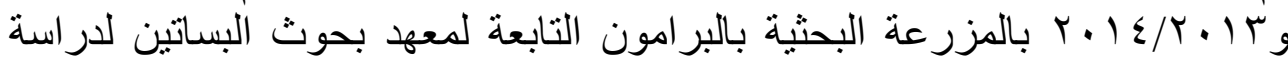

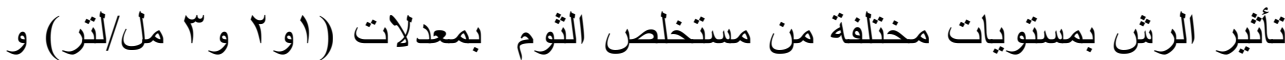

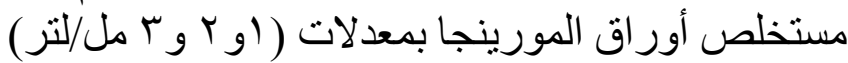

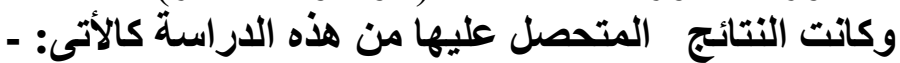

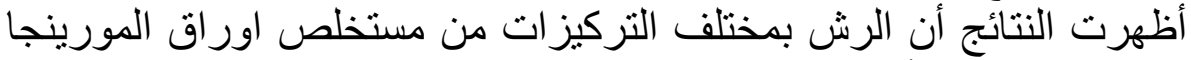

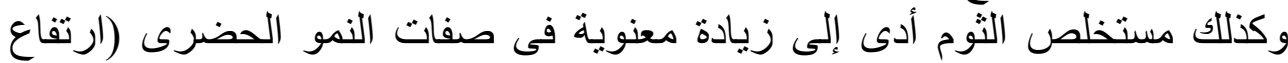

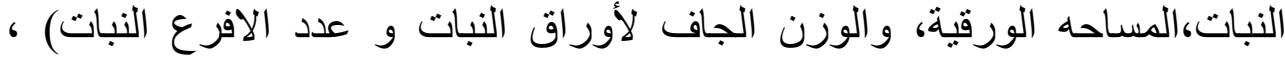

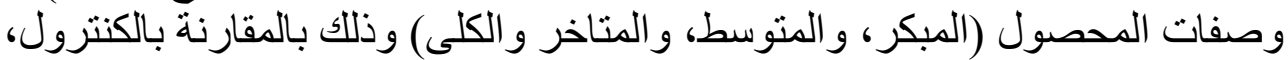

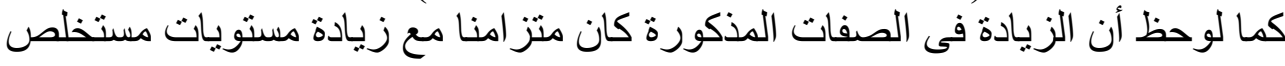

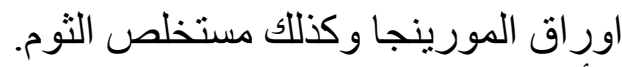

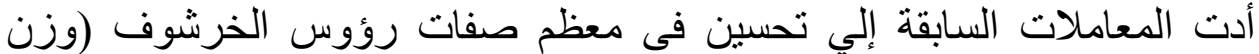

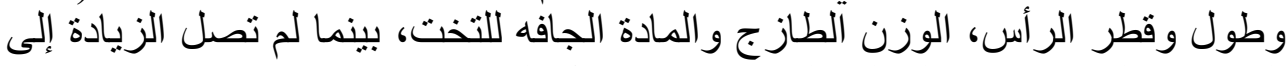

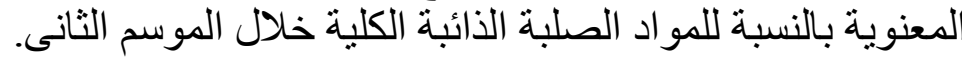

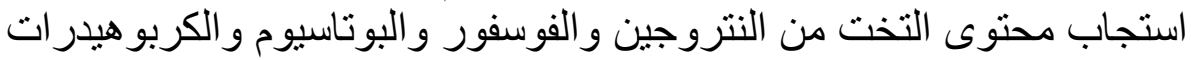
الكلية والسكريات الكلية والبروتين الكلى معنويا لمعاملات الرش الئن المذكورة خلال

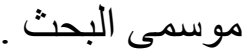

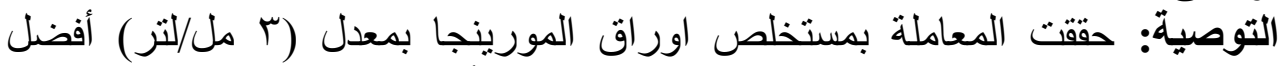

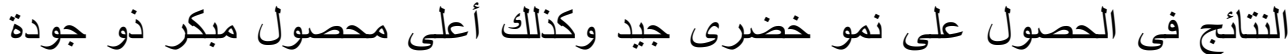
مرتفعة. و وعلاوة على ذللى، كانت هذه المعاملة أكثر فائدة مقارنة بجميع المعاملات 